\title{
Perencanaan Anaerobic Baffled Reactor (ABR) Sebagai Instalasi Pengolahan Greywater di Kecamatan Rungkut Kota Surabaya
}

\author{
Bias Agatha Permata Siswanto dan Ipung Fitri Purwanti \\ Jurusan Teknik Lingkungan, Fakultas Teknik Sipil dan Perencanaan, Institut Teknologi Sepuluh Nopember (ITS) \\ Jl. Arief Rahman Hakim, Surabaya 60111 Indonesia \\ e-mail: purwanti@enviro.its.ac.id
}

\begin{abstract}
Abstrak - Kecamatan Rungkut merupakan daerah yang mengalami perkembangan cukup pesat akibat berkembangnya sektor ekonomi. Perkembangan tersebut berimbas pada peningkatan jumlah penduduk yang berbanding lurus dengan peningkatan produksi air limbah domestik. Komposisi air limbah domestik sebesar $50-80 \%$ merupakan greywater. Sebagian besar masyarakat masih menyalurkan limbah greywater ke selokan yang berakibat pada pengendapan sludge sehingga mengurangi volume saluran serta pencemaran badan air ditandai dengan terjadinya peristiwa eutrofikasi. Oleh sebab itu diperlukan perencanaan instalasi pengolahan greywater di Kecamatan Rungkut.

Pengolahan greywater yang direncanakan adalah unit Anaerobic Baffled Reactor (ABR). Penggunaan ABR berdasarkan dengan pertimbangan kemudahan dalam operasional dan perawatan, aspek finansial serta ketersediaan lahan. Wilayah terlayani pada 3 kelurahan dengan penduduk terpadat yaitu Kelurahan Kedung Baruk, Penjaringan Sari, dan Rungkut Kidul.

Berdasarkan hasil perhitungan, instalasi pengolahan greywater yang direncanakan berdimensi $\mathrm{p} x \mathrm{l}$ x $\mathrm{t}$ sebesar 12,4 $\mathrm{m}$ x 2,3 m $x \quad 2,6 \mathrm{~m}$. Biaya minimal yang dibutuhkan untuk membangun unit ABR adalah Rp. 142.000.000,- dan maksimal sebesar Rp. 149.000.000,- untuk tipikal pelayanan 100 KK. Biaya pembangunan tersebut dipengaruhi oleh lokasi peletakan yaitu di jalan atau lahan kosong.
\end{abstract}

Kata Kunci- Air Limbah, Anaerobic Baffled Reactor, Greywater, Kecamatan Rungkut

\section{PENDAHULUAN}

$\mathrm{K}$ ECAMATAN Rungkut merupakan daerah yang mengalami perkembangan cukup pesat akibat dari berkembangnya sektor ekonomi. Berdasarkan Rencana Tata Ruang Wilayah (RTRW) Surabaya tahun 2015, Kecamatan Rungkut berada pada Unit Pengembangan I yang fungsi kegiatannya diarahkan untuk kegiatan permukiman, pendidikan, konservasi dan industri. Pengembangan fungsi kegiatan ini berakibat pada banyaknya pendatang dari berbagai daerah baik dari dalam maupun luar Surabaya [1]. Banyaknya pendatang akan berpengaruh terhadap pertambahan jumlah buangan air limbah oleh aktifitas rumah tangga, menjadikan salah satu sumber utama akumulasi pencemar di badan air [2]. Kecamatan Rungkut sendiri belum memiliki sistem penyaluran dan pengolahan air limbah yang terpadu.

Sistem penyaluran limbah yang biasa digunakan masyarakat yakni blackwater akan dialirkan ke dalam tangki septik dan diresapkan ke dalam tanah atau dibuang ke saluran umum. Sedangkan, greywater langsung disalurkan ke saluran drainase [3]. Komposisi air limbah domestik sebesar 50-80\% merupakan greywater [4]. Greywater merupakan air limbah non kakus hasil aktifitas rumah tangga, umumnya berasal dari kamar mandi, mesin cuci, dan dapur [5]. Greywater yang dibuang secara terus menerus ke dalam drainase dapat menimbulkan masalah bagi badan air karena zat organik yang terkandung dapat terdegradasi oleh mikroorganisme, menghasilkan lumpur dan gas. Akumulasi lumpur di dalam drainase menyebabkan pendangkalan dan berkurangnya volume saluran sehingga melebihi kapasitas ketika hujan [6]. Penyaluran greywater menuju drainase ini bertolak belakang dengan Peraturan Menteri Pekerjaan Umum No. 12 Tahun 2014 yang menganut sistem terpisah antara jaringan drainase dengan pengumpul air limbah.

Saat ini, banyak orang berpikir untuk menggunakan kembali air limbah dengan tujuan mengurangi konsumsi air bersih dan menjaga kelestarian lingkungan [7]. Pengelolaan greywater yang tepat dapat memberikan manfaat sebagai sumber air untuk keperluan perkebunan, pertanian, atau penggelontoran toilet [8]. Potensi tersebut dapat diwujudkan dengan perencanaan instalasi pengolahan greywater di Kecamatan Rungkut. Teknologi pengolahan dapat dipilih sesuai dengan aspek teknis, lingkungan, kebutuhan serta keinginan dari masyarakat. Anaerobic Baffled Reactor merupakan unit pengolahan yang terdiri dari kompartemen pengendap diikuti oleh beberapa reaktor baffle vertikal sehingga memaksa air limbah mengalir secara upflow [9].

\section{METODOLOGI PERENCANAAN}

\section{A. Ide Perencanaan}

Ide perencanaan didapatkan akibat terjadinya kesenjangan antara kondisi eksisting dengan kondisi ideal yang ingin dicapai oleh pemerintah. Tujuan perencanaan adalah merencanakan instalasi pengolahan greywater dengan biaya operasional dan pemeliharaan yang murah yaitu unit Anaerobic Baffled Reactor untuk pemukiman padat penduduk di Kecamatan Rungkut.

\section{B. Ruang Lingkup}

Ruang lingkup perencanaan ini adalah:

1. Kelurahan dengan tingkat kepadatan tertinggi di 
Kecamatan Rungkut, khususnya Kelurahan Kedung Baruk (6 RW), Penjaringan Sari (8 RW), dan Rungkut Kidul (6 RW). Pemilihan RW pelayanan berdasarkan faktor ketersediaan lahan (Gambar 1).

2. Air limbah yang diolah merupakan greywater hasil aktifitas rumah tangga.

3. Aspek perencanaan meliputi aspek teknis dan finansial.

4. Perencanaan desain bangunan pengolahan greywater dengan tipikal untuk 100KK.

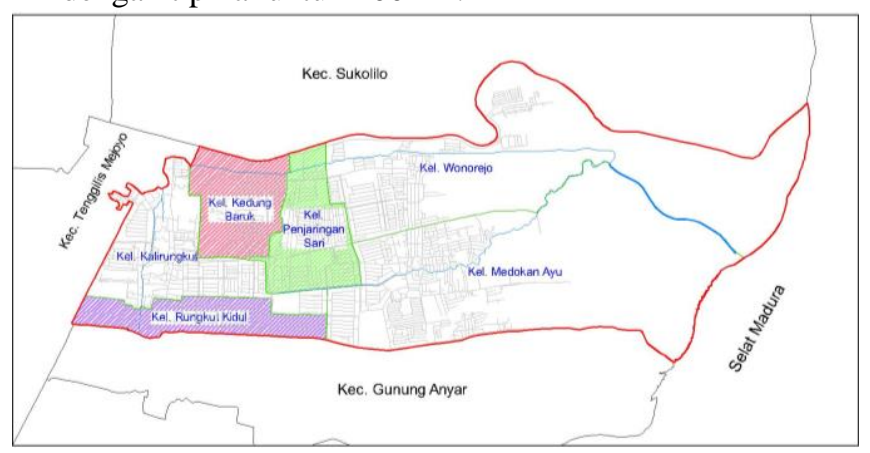

Gambar 1. Wilayah Pelayanan di Kecamatan Rungkut

\section{Pengumpulan Data}

Data yang dibutuhkan dalam perencanaan ini adalah data primer dan data sekunder. Data Primer meliputi data pemakaian air bersih warga, data kualitas air limbah dan ketersediaan lahan di wilayah perencanaan. Data pemakaian air bersih warga didapatkan dengan mengumpulkan nomor rekening pelanggan untuk dicari debitnya melalui website PDAM. Data kualitas air limbah didapatkan melalui hasil pengujian sampel greywater di laboratorium sedangkan data ketersedian lahan dilakukan dengan observasi dan pengukuran langsung di lapangan. Pengumpulan nomor rekening pelanggan dilakukan di tiga kelurahan dengan penentuan jumlah sampel menggunakan metode slovin, yaitu:

$$
\mathrm{n}=\frac{\mathrm{N}}{1+N e^{2}}
$$

Dimana:

$\mathrm{n}=$ ukuran sampel

$\mathrm{N}=$ ukuran populasi

$\mathrm{E}=$ taraf kesalahan (eror) sebesar 0,1 (10\%)

Jumlah sampel pada masing-masing kelurahan dapat dilihat pada Tabel 1.

Tabel 1.

Penentuan Jumlah Sampel

\begin{tabular}{clcc}
\hline \hline \multirow{2}{*}{ No. } & \multirow{2}{*}{ Kelurahan } & $\begin{array}{c}\text { Jumlah Populasi } \\
(\mathrm{KK})\end{array}$ & $\begin{array}{c}\text { Jumlah Sampel } \\
(\mathrm{KK})\end{array}$ \\
\hline 1 & Rungkut Kidul & 4083 & 28 \\
2 & Penjaringan Sari & 5386 & 37 \\
3 & Kedung Baruk & 4798 & 33 \\
& Total & 14267 & 99 \\
\hline \hline
\end{tabular}

Data sekunder yang dibutuhkan antara lain meliputi demografi kependudukan, peta wilayah perencanaan, baku mutu air limbah dan HSPK Kota Surabaya.

\section{HASIL PERENCANAAN}

\section{A. Proyeksi Penduduk}

Proyeksi penduduk dilakukan karena hasil proyeksi berpengaruh pada besarnya pemakaian air bersih dimasa mendatang. Jumlah pemakaian air bersih akan menentukan kuantitas debit air limbah yang mengalir menuju IPAL. Kecamatan Rungkut merupakan wilayah padat dan dapat dikatakan telah jenuh sehingga pada waktu tertentu laju pertumbuhan dan kematian berada pada tingkat yang sama. Penentuan proyeksi penduduk dengan kondisi daerah yang telah jenuh dapat dilakukan menggunakan metode analisa logaritmik. Berdasarkan hasil perhitungan didapatkan bahwa Kecamatan Rungkut mengalami kenaikan rata-rata pertumbuhan penduduk sebesar $1,12 \%$ dengan periode perencanaan selama 5 tahun yaitu hingga tahun 2020. Berdasarkan hasil proyeksi, jumlah KK terlayani di masingmasing kelurahan adalah 1392 KK pada Kelurahan Kedung Baruk, 2412 KK pada Kelurahan Penjaringan Sari, dan 1513 KK pada Kelurahan Rungkut Kidul.

\section{B. Debit Air Limbah}

Penentuan jumlah responden menggunakan metode slovin pada tiga kelurahan di Kecamatan Rungkut membutuhkan sampel sebanyak 99 responden, dengan asumsi 1 responden mewakili $1 \mathrm{KK}$. Total 99 responden tersebut disebarkan dengan rincian 28 sampel dari Kelurahan Rungkut Kidul, 37 sampel dari Kelurahan Penjaringan Sari, serta 33 sampel dari Kelurahan Kedung Baruk.

Debit pemakaian air bersih yang didapat melalui nomor rekening pelanggan menghasilkan rata-rata konsumsi air PDAM adalah 174 liter/orang/hari. Berdasarkan literatur [10], $80 \%$ dari pemakaian air bersih akan berubah menjadi air limbah dan $75 \%$ dari total air limbah tersebut merupakan greywater. Perencanaan ini difokuskan pada pengolahan greywater sehingga didapat debit air limbah sebesar 104,4 liter/orang/hari.

Instalasi pengolahan air limbah (IPAL) yang direncanakan merupakan tipikal untuk $100 \mathrm{KK}$ dengan asumsi $1 \mathrm{KK}$ terdiri dari 5 orang, maka jumlah penduduk terlayani oleh tiap unit IPAL adalah 500 orang. Debit air limbah rata-rata yang digunakan adalah $52200 \mathrm{~L} /$ hari atau $52,2 \mathrm{~m}^{3} /$ hari, atau 2,2 $\mathrm{m}^{3} / \mathrm{jam}$.

\section{Kualitas Air Limbah}

Kualitas air limbah didapat melalui analisa laboratorium terhadap sampel greywater yang diambil secara grab sampling dengan frekuensi pengambilan 1 minggu sekali selama 3 minggu berturut-turut pada 1 lokasi yang sama di masingmasing Kelurahan. Rata-rata kualitas air limbah di Kecamatan Rungkut yaitu:

- $\mathrm{BOD}=247,50 \mathrm{mg} / \mathrm{l}$

- $\mathrm{COD}=553,73 \mathrm{mg} / \mathrm{l}$

- $\mathrm{TSS}=244,82 \mathrm{mg} / \mathrm{l}$

- $\mathrm{pH}=7,09$

D. Desain IPAL

Desain perencanaan IPAL ini didasarkan pada rumus yang tertera di literatur [11]. Perhitungan dimensi unit ABR dibagi 
menjadi 2 tahap, yaitu zona tangki pengendap dan zona kompartemen. Lebar dan kedalaman unit pengolahan ditetapkan sesuai dengan kondisi ketersediaan lahan yaitu masing-masing sebesar $2 \mathrm{~m}$. Kriteria desain yang digunakan pada perencanaan kali ini adalah:

- Zona Tangki Pengendap

1. Periode Pengurasan $=2-3$ Tahun

2. Td tangki pengendap $=2-6 \mathrm{jam}$

3. $\mathrm{SS} / \mathrm{COD}=0,35-0,45$

- Zona Kompartemen

1. Organic Loading Rate $(\mathrm{OLR})=<3 \mathrm{KgCOD} / \mathrm{m}^{3}$.hari

2. Hydraulic Retention Time $(\mathrm{HRT})=8-20 \mathrm{jam}$

3. Kecepatan aliran (Vup) $=<2 \mathrm{~m} / \mathrm{jam}$

4. Panjang kompartemen $=50-60 \%$ kedalaman

Mengacu pada kriteria desain di atas, dimensi dan efisiensi removal unit ABR dapat dihitung sesuai dengan langkahlangkah sebagai berikut:

a. Perhitungan Zona Tangki Pengendap

1. Presentase removal COD diketahui setelah mendapatkan faktor removal COD. Penentuan faktor removal COD dengan cara menarik garis pada grafik removal COD terhadap HRT di tangki pengendap (Gambar 2). Waktu tinggal direncanakan selama 3 jam, sehingga didapatkan faktor removal COD sebesar 0,40. Direncanakan nilai rasio $\mathrm{SS} / \mathrm{COD}$ sebesar 0,42 .

2. Perkiraan presentase removal COD $=\underline{\text { rasio } \mathrm{SS} / \mathrm{COD}} \times$ faktor removal $=\frac{0,42,6}{0,6} 0,40=28 \%$

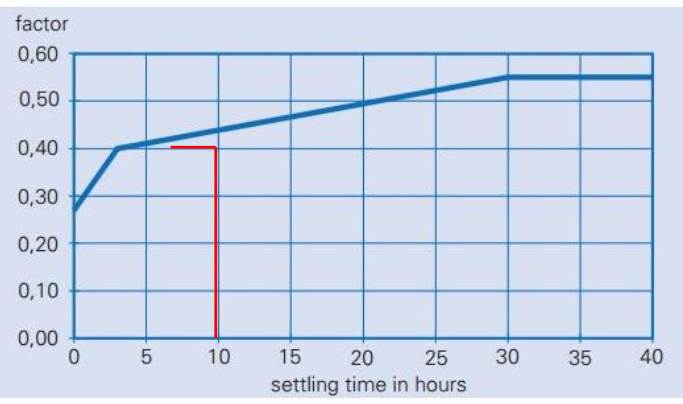

Gambar 2. Faktor Removal COD di Tangki Pengendap

3. Presentase removal BOD dapat ditentukan dengan mengetahui faktor removal BOD. Faktor removal BOD didapat melalui grafik hubungan antara faktor removal BOD terhadap removal COD (Gambar 3). Presentase removal COD diketahui sebesar 28\%, maka didapatkan faktor removal BOD adalah 1,06.

4. Perkiraan presentase removal BOD

$=$ Faktor removal $\mathrm{BOD} \times$ presentase removal $\mathrm{COD}$ $=1,06 \times 28 \%=30 \%$

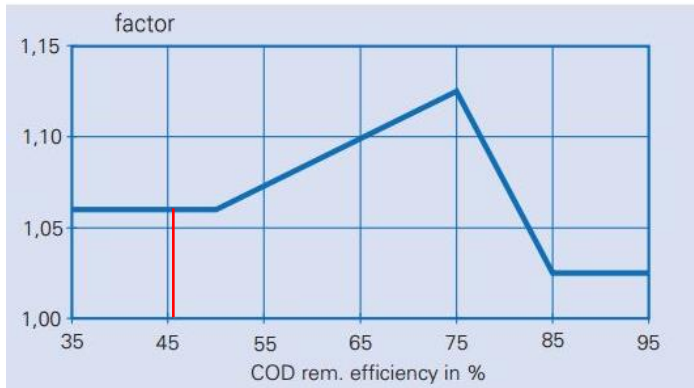

Gambar 3. Faktor removal BOD terhadap removal COD

5. Perhitungan dimensi tangki pengendap mengacu pada literatur dan kriteria desain.

Maka didapatkan dimensi dan persentase removal di Tangki Pengendap yaitu :

- Dimensi Tangki Pengendap

Lebar $=2$ meter

Panjang $=4$ meter

Kedalaman $=2$ meter

Freeboard $=0,3$ meter

- Persentase Removal di Tangki Pengendap

Removal $\mathrm{BOD}=30 \%$

Removal $\mathrm{COD}=28 \%$

b. Perhitungan Zona Kompartemen

1. Jumlah kompartemen ditentukan sebanyak 6 buah.

2. Perhitungan efisiensi removal COD dipengaruhi oleh faktor OLR (Gambar 4), faktor COD strength (Gambar 5), faktor temperatur (Gambar 6), dan faktor HRT (Gambar 7).

a. Laju beban organik yang masuk kedalam ABR sebesar $0,31 \mathrm{Kg} / \mathrm{m}^{3}$.hari sehingga diketahui nilai faktor OLR adalah 1 .

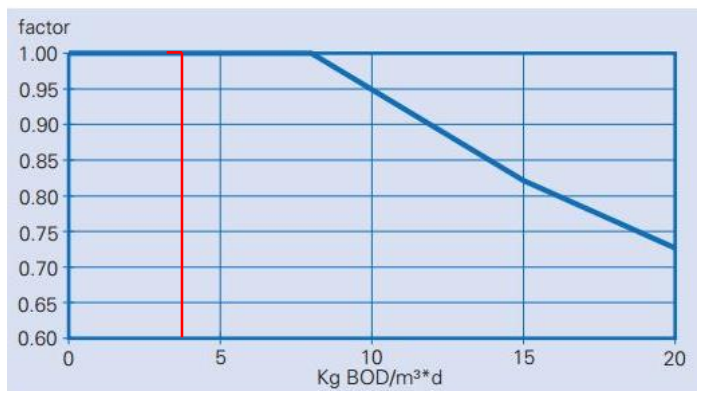

Gambar 4. Faktor OLR

b. Konsentrasi COD yang masuk kedalam ABR sebesar 398,69 mg/L sehingga diketahui nilai faktor COD strength adalah 0,9 .

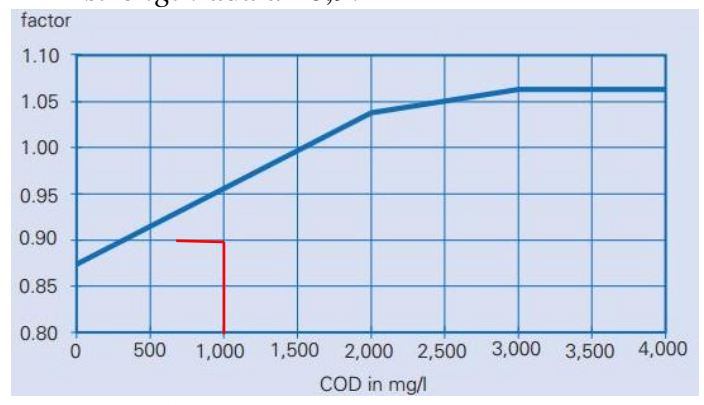

Gambar 5. Faktor COD Strength

c. Temperatur di dalam unit ABR ditetapkan sebesar $30^{\circ} \mathrm{C}$ sehingga diketahui nilai faktor temperatur adalah 1,1 . 


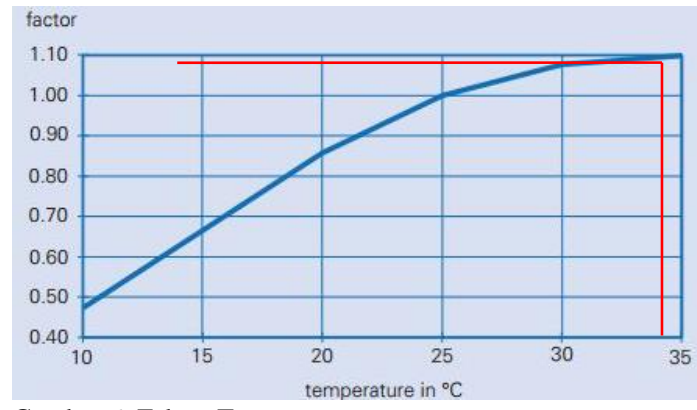

Gambar 6. Faktor Temperatur

d. Lamanya waktu tinggal air limbah di dalam reaktor adalah 13 jam sehingga didapatkan nilai faktor sebesar 0,85 .

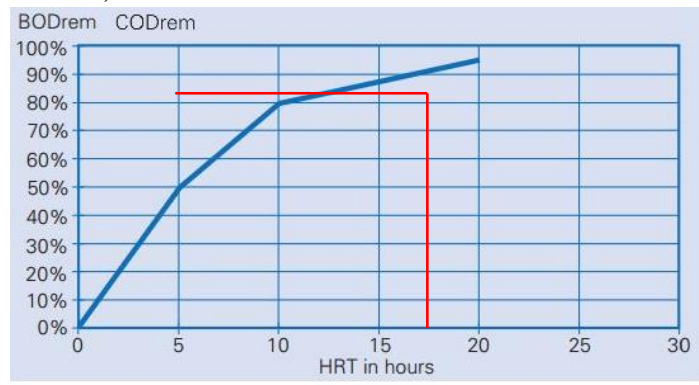

Gambar 7. Faktor HRT

3. Perhitungan efisiensi removal BOD dengan menggunakan grafik faktor removal BOD terhadap removal COD di kompartemen (Gambar 8)

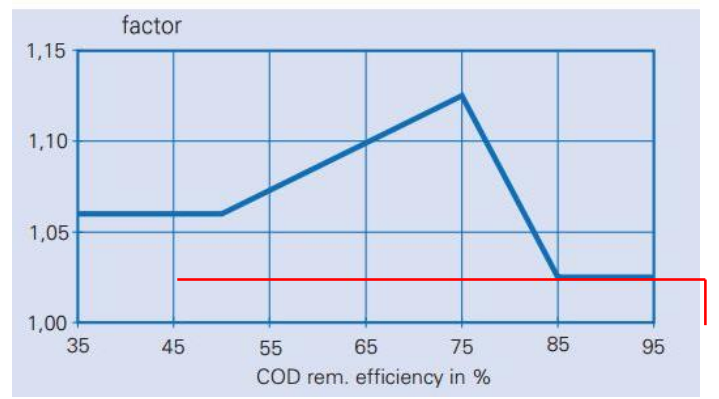

Gambar 8. Faktor removal BOD terhadap removal COD di kompartemen Maka didapatkan dimensi dan persentase removal di Kompartemen yaitu:

- Dimensi Kompartemen

$\begin{array}{ll}\text { Lebar } & =2 \text { meter } \\ \text { Kedalaman } & =2 \text { meter } \\ \text { Panjang } & =60 \% \text { kedalaman } \\ & =1,2 \text { meter } \\ \text { Freeboard } & =0,3 \text { meter } \\ \text { Jumlah Kompartemen } & =6 \text { buah }\end{array}$

- Persentase Removal di Kompartemen

Removal BOD $=93 \%$

Removal COD $=90 \%$

Konstruksi yang digunakan untuk unit ABR direncanakan menggunakan material beton bertulang dengan asumsi daya tekan yang lebih kuat serta memiliki lifetime lebih lama. Direncanakan ketebalan beton 0,15 meter. Sehingga dimensi total unit ABR adalah:

Lebar $\quad=2,3$ meter

Panjang $\quad=12,4$ meter

Kedalaman $=2,6$ meter
Tampak Atas dan Denah ABR yang direncanakan dapat dilihat pada Gambar 9, dan Potongan memanjang pada Gambar 10, serta Potongan melintang pada Gambar 11.

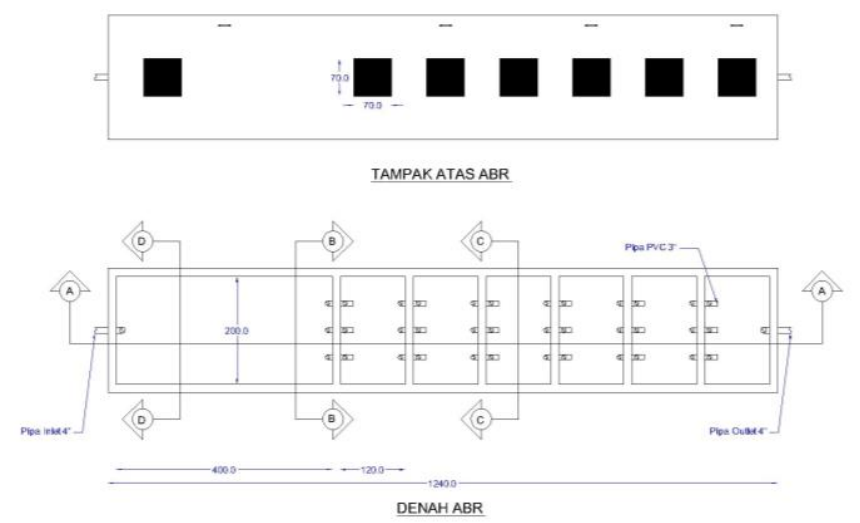

Gambar 9. Tampak Atas dan Denah ABR

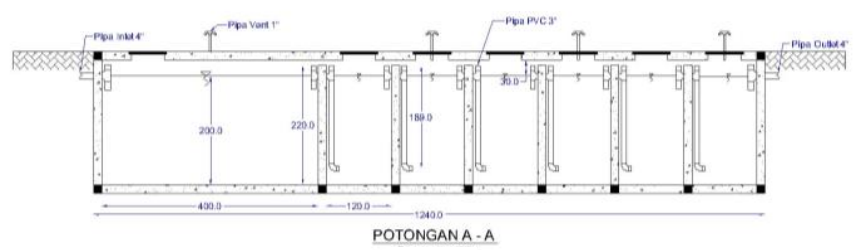

Gambar 10. Potongan Memanjang ABR (A-A)

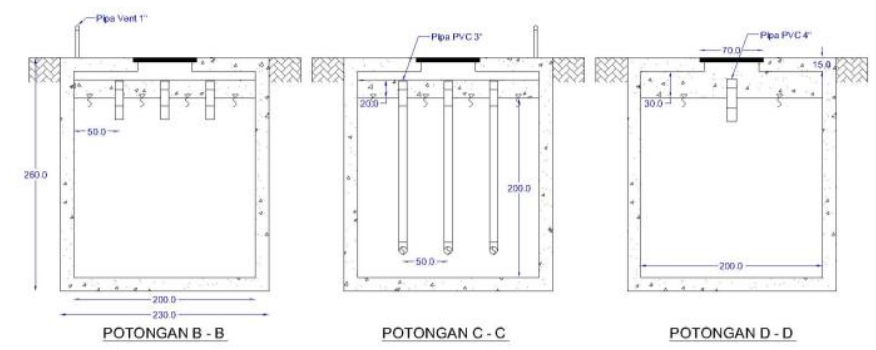

Gambar 11. Potongan Melintang ABR (B-B, C-C, D-D)

\section{E. Peletakan IPAL}

IPAL dapat diletakkan pada lahan kosong. Apabila tidak tersedia lahan kosong, IPAL dapat diletakkan di jalan. Wilayah di Kecamatan Rungkut sendiri memiliki 2 tipe jalan, yaitu jalan berpaving dan beraspal. Contoh rencana peletakan IPAL di lahan kosong, jalan paving dan aspal adalah sebagai berikut:

a. Wilayah RW 07 Kelurahan Kedung Baruk

Diletakkan pada lahan kosong, dengan luas lahan 42,5 meter x 39 meter (Gambar 12).

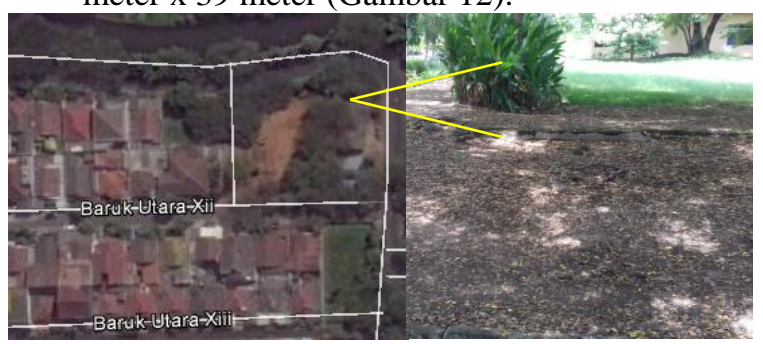

Gambar 12. Lokasi Penempatan IPAL RW 07 Kel. Kedung Baruk

b. Wilayah RW 11 Kelurahan Penjaringan Sari 
Diletakkan di Jalan Pandugo Sari X (beraspal) dengan lebar jalan 6 meter (Gambar 13).

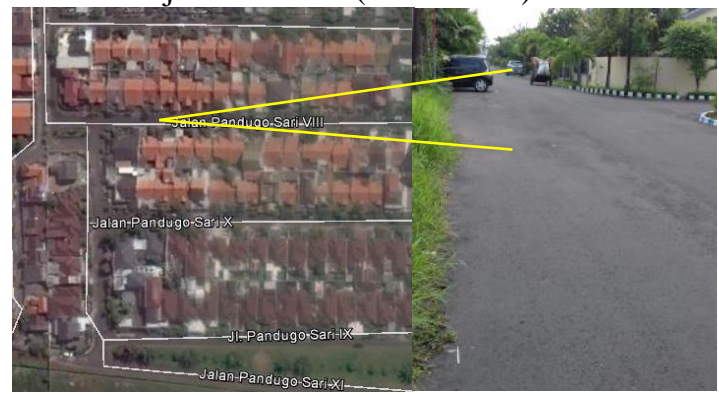

Gambar 13. Lokasi Penempatan IPAL RW 11 Kel. Penjaringan Sari

c. Wilayah RW 10 Kelurahan Rungkut Kidul

Diletakkan di Jalan Medokan Asri Barat (berpaving) dengan lebar jalan 6,1 meter (Gambar 14)

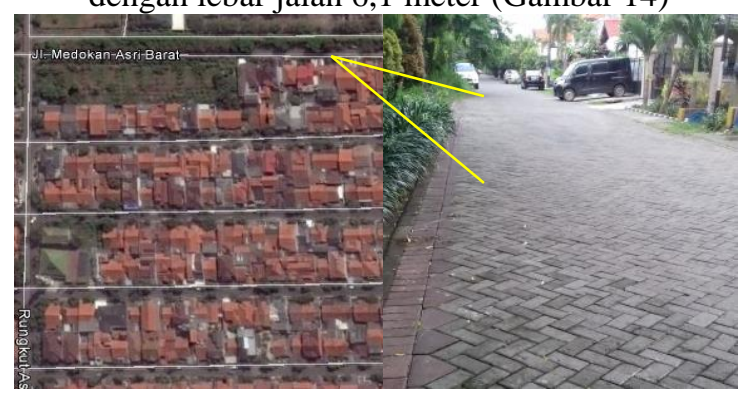

Gambar 14. Lokasi Penempatan IPAL RW 10 Kel. Rungkut Kidul

\section{RENCANA ANGGARAN BIAYA}

Rencana anggaran biaya (RAB) diperoleh dari hasil perkalian antara volume pekerjaan dengan harga satuan pokok kerja (HSPK). Harga satuan pokok pekerjaan disesuaikan dengan HSPK Kota Surabaya Tahun 2015. Lokasi peletakan IPAL akan berpengaruh terhadap RAB, dimana pelatakan pada lahan kosong akan menghasilkan biaya yang lebih rendah dibanding peletakan di jalan. Rencana anggaran biaya untuk pembangunan unit ABR pada masing-masing lokasi yang direncanakan tertera pada Tabel $2-4$.

Tabel 2.

Rencana Anggaran Biaya (Jalan Berpaving)

\begin{tabular}{|c|c|c|c|}
\hline \multicolumn{4}{|c|}{ BOQ dan RAB Pembangunan ABR } \\
\hline NO & Tahapan Konstruksi & Satuan & $\begin{array}{l}\text { Total Biaya } \\
(\mathrm{Rp})\end{array}$ \\
\hline \multicolumn{4}{|c|}{ Tahap Persiapan } \\
\hline 1 & $\begin{array}{l}\text { Pembersihan Lapangan "Ringan" } \\
\text { dan Perataan }\end{array}$ & $\mathrm{m}^{2}$ & 351.549 \\
\hline 2 & $\begin{array}{l}\text { Pembongkaran Paving tidak } \\
\text { dipakai Kembali }\end{array}$ & $\mathrm{m}^{2}$ & 140.620 \\
\hline 3 & Pembuatan Bouwplank & $\mathrm{m}$ & 3.221 .430 \\
\hline \multicolumn{4}{|c|}{$\begin{array}{r}\text { Pekerjaan Utama } \\
\end{array}$} \\
\hline 1 & $\begin{array}{l}\text { Penggalian Tanah Biasa } \\
\text { Pengangkutan Tanah dari Lubang }\end{array}$ & $\mathrm{m}^{3}$ & 8.881 .587 \\
\hline 2 & $\begin{array}{l}\text { Galian Dalamnya Lebih Dari } \\
\text { 1meter }\end{array}$ & $\mathrm{m}^{3}$ & 1.810 .809 \\
\hline 3 & Pekerjaan Plat Lantai Beton & $\mathrm{m}^{3}$ & 13.081 .265 \\
\hline 4 & Pekerjaan Kolom Beton Bertulang & $\mathrm{m}^{3}$ & 5.620 .473 \\
\hline 5 & Pekerjaan Balok Beton Bertulang & $\mathrm{m}^{3}$ & 11.105 .311 \\
\hline 6 & Pekerjaan Dinding Beton Bertulang & $\mathrm{m}^{3}$ & 78.332 .190 \\
\hline 7 & Pekerjaan Plat Tutup Beton & $\mathrm{m}^{3}$ & 13.081 .265 \\
\hline 8 & $\begin{array}{l}\text { Pemasangan Pipa Air Kotor } \\
\text { diameter 3" }\end{array}$ & $\mathrm{m}$ & 1.826 .664 \\
\hline 9 & Pemasangan Pipa Air Kotor & $\mathrm{m}$ & 128.382 \\
\hline
\end{tabular}

diameter 4"

\begin{tabular}{lllr}
\hline \multicolumn{3}{c}{ Pekerjaan Finishing } & \\
\hline 1 & Pelapisan Waterproof & $\mathrm{m}^{2}$ & 4.112 .472 \\
2 & Pengurugan Tanah Kembali & $\mathrm{m}^{3}$ & 505.270 \\
3 & Pembersihan Lapangan "Berat" dan & $\mathrm{m}^{2}$ & 703.098 \\
\hline \multicolumn{2}{c}{ Perataan } & & 142.902 .384 \\
\hline \hline
\end{tabular}

Tabel 3.

Rencana Anggaran Biaya (Lahan Kosong) BOQ dan RAB Pembangunan ABR

\begin{tabular}{|c|c|c|c|}
\hline \multicolumn{4}{|c|}{ BOQ dan RAB Pembangunan ABR } \\
\hline NO & Tahapan Konstruksi & Satuan & $\begin{array}{l}\text { Total Biaya } \\
\text { (Rp) }\end{array}$ \\
\hline \multicolumn{4}{|c|}{ Tahap Persiapan } \\
\hline 1 & $\begin{array}{l}\text { Pembersihan Lapangan "Ringan" dan } \\
\text { Perataan }\end{array}$ & $\mathrm{m}^{2}$ & 351.549 \\
\hline 2 & Pembuatan Bouwplank & $\mathrm{m}$ & 3.221 .430 \\
\hline \multicolumn{4}{|c|}{ Pekerjaan Utama } \\
\hline 1 & Penggalian Tanah Biasa & $\mathrm{m}^{3}$ & 8.881 .587 \\
\hline 2 & $\begin{array}{l}\text { Pengangkutan Tanah dari Lubang } \\
\text { Galian Dalamnya Lebih Dari 1meter }\end{array}$ & $\mathrm{m}^{3}$ & 1.810 .809 \\
\hline 3 & Pekerjaan Plat Lantai Beton & $\mathrm{m}^{3}$ & 12.485 .121 \\
\hline 4 & Pekerjaan Kolom Beton Bertulang & $\mathrm{m}^{3}$ & 5.620 .473 \\
\hline 5 & Pekerjaan Balok Beton Bertulang & $\mathrm{m}^{3}$ & 11.105 .311 \\
\hline 6 & Pekerjaan Dinding Beton Bertulang & $\mathrm{m}^{3}$ & 78.332 .190 \\
\hline 7 & Pekerjaan Plat Tutup Beton & $\mathrm{m}^{3}$ & 12.485 .121 \\
\hline 8 & $\begin{array}{l}\text { Pemasangan Pipa Air Kotor diameter } \\
\text { 3" }\end{array}$ & $\mathrm{m}$ & 1.796 .439 \\
\hline 9 & $\begin{array}{l}\text { Pemasangan Pipa Air Kotor diameter } \\
\text { 4" }\end{array}$ & $\mathrm{m}$ & 120.432 \\
\hline \multicolumn{4}{|c|}{$\begin{array}{r}\text { Pekerjaan Finishing } \\
\end{array}$} \\
\hline 1 & Pelapisan Waterproof & $\mathrm{m}^{2}$ & 4.112 .472 \\
\hline 2 & Pengurugan Tanah Kembali & $\mathrm{m}^{3}$ & 505.270 \\
\hline 3 & $\begin{array}{l}\text { Pembersihan Lapangan "Berat" dan } \\
\text { Perataan }\end{array}$ & $\mathrm{m}^{2}$ & 703.098 \\
\hline & TOTAL BIAYA & & 141.531 .301 \\
\hline
\end{tabular}

Tabel 4.

Rencana Anggaran Biaya (Jalan Aspal) BOQ dan RAB Pembangunan ABR

\begin{tabular}{|c|c|c|c|}
\hline \multicolumn{4}{|c|}{ BOQ dan RAB Pembangunan ABR } \\
\hline NO & Tahapan Konstruksi & Satuan & $\begin{array}{l}\text { Total Biaya } \\
\text { (Rp) }\end{array}$ \\
\hline \multicolumn{4}{|c|}{ Tahap Persiapan } \\
\hline 1 & $\begin{array}{l}\text { Pembersihan Lapangan "Ringan" } \\
\text { dan Perataan }\end{array}$ & $\mathrm{m}^{2}$ & 351.549 \\
\hline 2 & Pembuatan Bouwplank & $\mathrm{m}$ & 3.221 .430 \\
\hline \multicolumn{4}{|c|}{$\begin{array}{r}\text { Pekerjaan Utama } \\
\end{array}$} \\
\hline 1 & Penggalian Perkerasan Jalan & $\mathrm{m}^{2}$ & 5.970 .938 \\
\hline 2 & Penggalian Tanah Biasa & $\mathrm{m}^{3}$ & 8.881 .587 \\
\hline 3 & $\begin{array}{l}\text { Pengangkutan Tanah dari Lubang } \\
\text { Galian Dalamnya Lebih Dari } \\
\text { 1meter }\end{array}$ & $\mathrm{m}^{3}$ & 1.810 .809 \\
\hline 4 & Pekerjaan Plat Lantai Beton & $\mathrm{m}^{3}$ & 13.081 .265 \\
\hline 5 & Pekerjaan Kolom Beton Bertulang & $\mathrm{m}^{3}$ & 5.620 .473 \\
\hline 6 & Pekerjaan Balok Beton Bertulang & $\mathrm{m}^{3}$ & 11.105 .311 \\
\hline 7 & Pekerjaan Dinding Beton Bertulang & $\mathrm{m}^{3}$ & 78.332 .190 \\
\hline 8 & Pekerjaan Plat Tutup Beton & $\mathrm{m}^{3}$ & 13.081 .265 \\
\hline 9 & $\begin{array}{l}\text { Pemasangan Pipa Air Kotor } \\
\text { diameter 3" }\end{array}$ & $\mathrm{m}$ & 1.826 .664 \\
\hline 10 & $\begin{array}{l}\text { Pemasangan Pipa Air Kotor } \\
\text { diameter 4" }\end{array}$ & $\mathrm{m}$ & 128.382 \\
\hline \multicolumn{4}{|c|}{$\begin{array}{l}\text { Pekerjaan Finishing } \\
\end{array}$} \\
\hline 1 & Pelapisan Waterproof & $\mathrm{m}^{2}$ & 4.112 .472 \\
\hline 2 & Pengurugan Tanah Kembali & $\mathrm{m}^{3}$ & 505.270 \\
\hline 3 & $\begin{array}{l}\text { Pembersihan Lapangan "Berat" dan } \\
\text { Perataan }\end{array}$ & $\mathrm{m}^{2}$ & 703.098 \\
\hline \multicolumn{3}{|c|}{ TOTAL BIAYA } & 148.732 .702 \\
\hline
\end{tabular}

Berdasarkan Tabel 2, 3, dan 4 dapat dilihat bahwa 
perbedaan biaya dari ketiga lokasi tersebut adalah pada tahap persiapan dan pekerjaan utama. Peletakan pada jalan berpaving membutuhkan tambahan pekerjaan pembongkaran paving pada tahap persiapan, sedangkan peletakan pada jalan aspal membutuhkan tambahan pekerjaan penggalian perkerasan jalan pada tahap pekerjaan utama.

\section{KESIMPULAN}

1. Kecamatan Rungkut dapat menerapkan Anaerobic Baffled Reactor (ABR) sebagai instalasi pengolahan greywater untuk tipikal pelayanan $100 \mathrm{KK}$ dengan dimensi panjang $\mathrm{x}$ lebar x tinggi adalah $12,4 \mathrm{~m} \times 2,3 \mathrm{~m} \times 2,6 \mathrm{~m}$.

2. Biaya yang dibutuhkan untuk membangun instalasi pengolahan greywater dengan tipikal pelayanan $100 \mathrm{KK}$ di Kecamatan Rungkut bergantung pada lokasi peletakan. IPAL yang diletakkan pada jalan berpaving membutuhkan biaya sebesar Rp 142.902.384, apabila diletakan pada lahan kosong membutuhkan biaya $\mathrm{Rp} 141.531 .301$, dan peletakan pada jalan aspal membutuhkan biaya sebesar $\mathrm{Rp}$ 148.732.702.

\section{DAFTAR PUSTAKA}

[1] O. Vidianti dan P. G. Ariastita, "Arahan Penataan Permukiman di Kelurahan Kalirungkut Surabaya", thesis, Jurusan Perencanaan Wilayah dan Kota, ITS, Surabaya (2011)

[2] J. C. C. Mende, V. A. Kumurur, dan I. L. Moniaga, "Kajian Sistem Pengelolaan Air Limbah pada Permukiman Kawasan Sekitar Danau Tondano (Studi Kasus: Kecamatan Remboken Kabupaten Minahasa)”, Jurnal Binaan dan Arsitektur, Universitas Sam Ratulangi, Makassar (2015)

[3] A. Zubair, K. Riswal, dan Wulandari, "Studi Identifikasi Lokasi Pembangunan IPAL Komunal dan Evaluasi IPAL Komunal yang Ada di Kecamatan Panakukkang Makassar,, Jurnal Teknik Sipil, Universitas Hasanuddin Makassar (2015)

[4] E. C. Ukpong dan J. C. Agunwamba, "Grey Water Reuse for Irrigation", International Journal of Applied Science and Technology, Vol. 2 No. 8 (2012)

[5] B. Jefferson, A. Palmer, P. Jeffrey, R. Stuetz, dan S. Judd, "Grey water characterization and its impact on the selection and operation of technologies for urban reuse", Water Science and Technology Journal, Vol. 50 No. 2 (2004)

[6] A. Santoso, "Perencanaan Pengolahan Air Limbah Domestik dengan Alternatif media Biofilter (Studi Kasus : Kejawan Gebang Kelurahan keputih Surabaya)", Prosiding Seminar Nasional Manajemen Teknologi XXII; Surabaya, Indonesia, 24 Januari 2015

[7] S. I. Pratiwi dan E. S. Soedjono, "Studi Replikasi IPAL Grey Water Tepat Guna Berbasis Surabaya Green and Clean", Prosiding Seminar Nasional Manajemen Teknologi XXII; Surabaya, Indonesia, 24 Januari 2015.

[8] D. Widianti dan M. Handajani, "Studi Karakteristik Greywater untuk Melihat Potensi Pemanfaatan Greywater di Kota Bandung", Tugas Akhir. Program Studi Teknik Lingkungan ITB (2010).

[9] E. Tilley, L. Ulrich, C. Lüthi, P. Reymond, dan C. Zurbrügg, "Compendium of Sanitation Systems and Technologies $2^{\text {nd }}$ revised edition”, Dübendorf: EAWAG.

[10] J. Supriyanto, "Kajian Penggunaan Reaktor Biofilter untuk Pengolahan Greywater di Kawasan Pemukiman Atas Air Kelurahan Margasari Kota Balikpapan Menuju Konsep Zero Waste", Thesis, Universitas Gadjah Mada Yogyakarta (2014).

[11] L. Sasse, B. Gutterer, T. Panzerbieter, dan T. Reckerzugel, "Decentralised Wastewater Treatment Systems (DEWATS) and Sanitation in Developing Countries", UK: BORDA (2009) 